\title{
ANNUAL VARIATION OF THE FISH COMMUNITY COMPOSITION IN THE UREDERRA RIVER (NAVARRA, SPAIN)
}

\author{
F. Campos, J.M. Lekuona, C. Garcia-Fresca, J. Oscoz, R. Miranda, C. De la Riva, \& M.C. Escala \\ Departamento de Zoología y Ecologia. Facultad de Ciencias. Universidad de Navarra. 31080 Pamplona, Navarra (Espafia).
}

Key words: Fish diversity, Annual variation, Urederra River, Spain.

Palabras clave: Diversidad piscicola, variación anual, Rio Urederra, Espafia.

\begin{abstract}
The variation of the distribuffon of fish species as a function of the habitat during one year has been studied in the Urederra River (Navarra, northern Spain). Electrofishing samples, taken at eight points in September 1994, May 1995 and September 1995, using the catch-effort method, were compared. The relative abundance, diversity, dominance and species richness were calculated. Both native (Anguilla anguilla, Salmo trutta fario...) and introduced (Gobio gobio, Onchorhynchus mykiss) species were detected. Man-made modifications at some points of the river probably affected the relative abundance measured for the species.
\end{abstract}

\section{INTRODUCTION}

Longitudinal patterns of fish distribution in rivers have been studied in Europe (GARCÍA DE JALON \& LOPEZ ÁLVAREZ 1983, STARMACH et al. 1991, GARCÍA DE JALON 1992, PRZYBYLSKI 1993). Differences in fish distribution are related to environmental heterogeneity (GARCÍA DE JALON \& LOPEZ ALVAREZ 1983, ZALEWSKI et al. 1990, COLLARES-PEREIRA et al. 199.5) and to alterations of the water course (COPP \& BENNETTS 1996). River dredgings and riparian and instream cover removals lead to decreases in salmonid (KENNEDY et al. 1983) and cyprinid populations (COPP \& BENNETTS 1996).

Other characteristics such as river width, depth, bottom substratum and dissolved oxygen also influence fish communities (SCHLOSSER 1988, STARMACH et al. 1991, COLLARES-PEREIRA et al. 1995).

In this study fish assemblages along a small river are analysed as well as the possible influence that some biotic and abiotic factors may have on it.

\section{MATERIAL AND METHODS}

The Urederra River (North of Spain) starts from a karstic source situated at an altitude of $750 \mathrm{~m}$ and flows into the Ega River (Ebro basin). Its length is $20 \mathrm{~km}$ and the mean slope is $0.8 \%$. Calcareous slabs, rocks and boulders of different size form the bed. The riparian vegetation is made up of shrubs and trees (Willow Salix sp., Ash tree Fraxinus excelsior L., Hazel tree Corylus avellana L., Poplar Populus alba L. and Black poplar Populus nigra L.). Erection of dams and dredging of the river bed have modified the original morphology of the river.

Samples were taken in September 1994, May and September 1995 at eight points (Fig. 1) whose main physical and chemical characteristics are presented in Table 1.

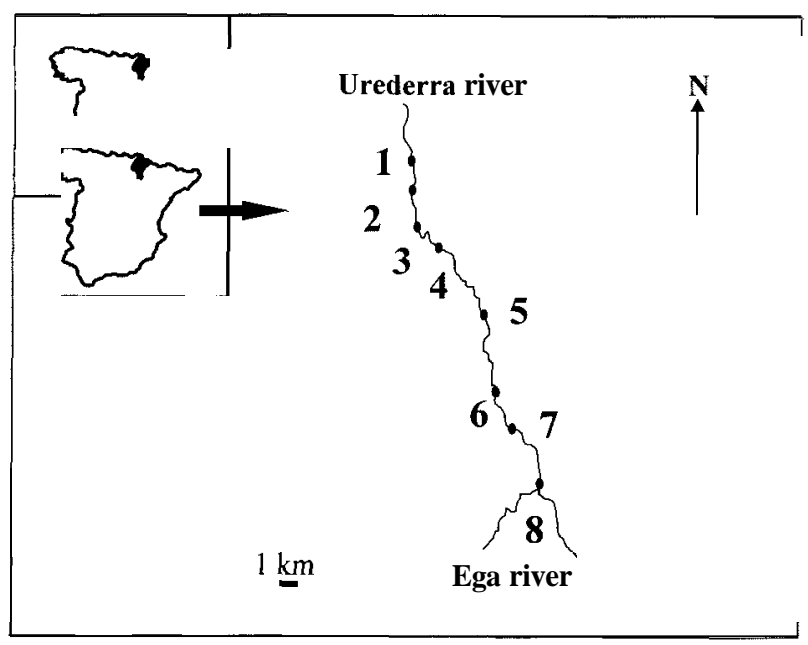

FIGURE 1. Location of the sampling sites in the Urederra River (Navarra, North of Spain). Sampling stations: 1: Baquedano, 2: Zudaire, 3: Arzata, 4: Itako, 5: Artavia, 6: Galdeano, 7: Euliz, 8: Estella. 
TABLE I. Physical and chemical characteristics in the Urederra River in a) September 1994 b) May 1995 c) September 1995

\begin{tabular}{|c|c|c|c|c|c|c|c|c|c|c|c|c|c|c|c|c|c|c|c|c|c|c|c|c|}
\hline \multirow[b]{2}{*}{ Parameters } & \multicolumn{24}{|c|}{ Sampling stations } \\
\hline & \multicolumn{4}{|c|}{1} & \multicolumn{2}{|l|}{2} & \multicolumn{3}{|c|}{3} & \multicolumn{3}{|c|}{4} & \multicolumn{3}{|c|}{5} & \multicolumn{3}{|c|}{6} & \multicolumn{3}{|c|}{7} & \multicolumn{3}{|c|}{8} \\
\hline Altitude (m) & & 540 & & & 520 & & & 520 & & & 500 & & & 480 & & & 460 & & & 440 & & & 430 & \\
\hline $\begin{array}{l}\text { Distance } \\
\text { from origin }(\mathbf{k m})\end{array}$ & & 2.4 & & & 3.3 & & & 4.5 & & & 6.5 & & & 11.0 & & & 14.2 & & & 16.1 & & & 19.7 & \\
\hline \multirow{2}{*}{$\begin{array}{l}\text { Sampling area } \\
\left(\mathbf{m}^{2}\right)\end{array}$} & & 1193 & & & 1357 & & & 886 & & & 780 & & & 1194 & & & 929 & & & 1022 & & & 761 & \\
\hline & a & b & c & $\mathbf{a}$ & b & c & a & b & c & $\mathbf{a}$ & b & c & $\mathbf{a}$ & b & c & $\mathbf{a}$ & b & c & $\mathbf{a}$ & b & c & a & b & c \\
\hline Width (m) & 12 & 12 & 12 & 9 & 9 & 8 & 9 & 9 & 8 & 9 & 8 & 8 & 14 & I6 & 14 & 7 & 14 & 14 & 10 & 11 & 10 & 9 & 11 & 9 \\
\hline Depth (cm) & 58 & 61 & 59 & 58 & 31 & 31 & 34 & 34 & 32 & 75 & 85 & 56 & 51 & 40 & 46 & 34 & 20 & 25 & 71 & 83 & 66 & 57 & 50 & 68 \\
\hline $\begin{array}{l}\text { Temperature } \\
\left({ }^{\circ} \mathrm{C}\right)\end{array}$ & 11.6 & 11.2 & 11.6 & 10.3 & 129 & 11.3 & 11.5 & 99 & 11.3 & 10.9 & 11.3 & 11.8 & 13.4 & 142 & 146 & 152 & 16.4 & 145 & 152 & 154 & 146 & 14.8 & 136 & 14.4 \\
\hline pH & 80 & 85 & 76 & 74 & 79 & 74 & 66 & 79 & 70 & 76 & 83 & 73 & 80 & 85 & 80 & 7.9 & 78 & 81 & 79 & 68 & 79 & 83 & 81 & 78 \\
\hline $\begin{array}{l}\text { Conductivity } \\
(\mu S)\end{array}$ & 363 & 402 & 356 & 424 & 453 & 376 & 456 & 458 & 439 & 402 & 605 & 628 & 439 & 498 & 426 & 444 & 498 & 445 & 517 & 503 & 507 & 487 & 510 & 498 \\
\hline $\begin{array}{l}\text { Oxygen } \\
\text { (ppm) }\end{array}$ & 11.0 & 10.6 & 10.0 & 11.3 & 120 & 10.0 & 6.7 & 93 & 5.9 & 54 & 10.7 & 7.6 & 13.0 & 12.7 & 11.7 & 12.5 & 122 & 12.9 & 94 & 12.5 & 10.5 & 10.4 & 10.1 & 9.1 \\
\hline
\end{tabular}

Fish were captured by electrofishing using two stopnets limiting each sampling site. Three consecutive removals were made following the catch-effort method (PENCZAK \& ZALEWSKI 1981, PENCZAK et al. 1981). Fish species diversity (Shannon's diversity index $H^{\prime}=-\Sigma p_{i} \log _{2} p_{i}$ ), dominance (Simpson's dominance index $\mathrm{D}=\Sigma \mathrm{p}_{\mathrm{i}}{ }^{2}$ ) and species richness (Margalef's diversity index $\mathrm{R}=(\mathrm{S}-1) / \ln \mathrm{N})$, where $\mathrm{p}$, is the proportion of the abundance of species " $\mathrm{i}$ " at a given site, $\mathrm{S}$ is the number of species and $\mathrm{N}$ is the total number of fish captures, were calculated (MARGALEF, 1989).

Frequencies were compared using the $\chi^{2}$ test with Yates correction when necessary (SOKAL \& ROHLF, 1979).

\section{RESULTS}

The fish fauna of the Urederra River is shown in Figure 2. Alltogether eight fish species were found in the eight stations during the sampling period: Brown trout (Salmo trutta fario L.), Rainbow trout (Onchorhynchus mykiss (Walb.)), Minnow (Phoxinus phoxinus (L.)), French nase (Chondrostoma toxostoma (Vallot)), Barbel (Barbus graellsii Steind.), Gudgeon (Gobio gobio (L.)), Stone loach (Barbatula barbatula (L.)) and Eel (Anguilla anguilla (L.)). Brown trout was the most numerous species in the first three sampling stations $\left(\chi^{2}=283.2, \chi^{2}=109.4\right.$ and $\chi^{2}=600.9$, respectively, all comparisons $1 \mathrm{df}, \mathrm{P}<0.001$ ), but its frequency decreased significantly downstream being replaced by minnow

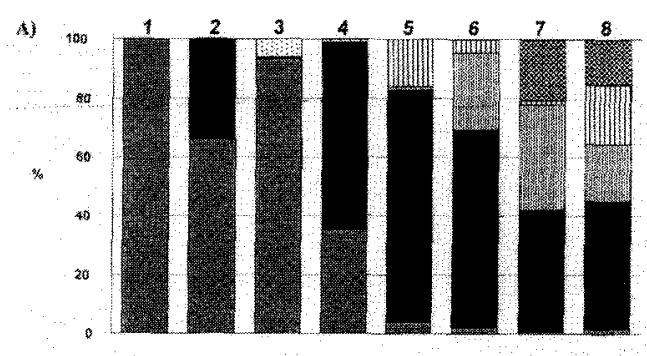

13)

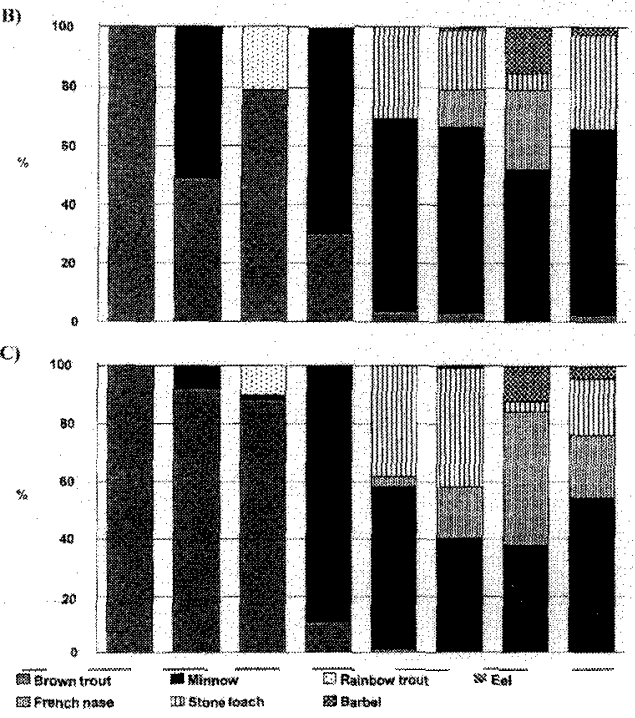

FIGURE 2 Fish fauna composition in \% ot the Urederra River A) September 1994, B) May 1995 and C) September 1995. 
On the basis of the differences detected in fish distribution in this river, two sections could be distinguished: the upper, salmonid course (sampling stations 1 to 3 ) and the lower, cyprinid course (rest of stations). This was also observed in the calculated indices (Figure 3). Fish diversity was null in the first station, increased slightly towards station 4 and reached its highest value near the confluence with Ega River.

Species richness followed a similar pattern. At station 3 its value was higher than expected probably due to the existence of a fish-farm which also explained the presence of rainbow trout in the station.

Dominance was maximum at station 1 (exclusive presence of brown trout), decreased slightly down to station 4 , at station 5 there was a strong decrease which continued down to station 8 .
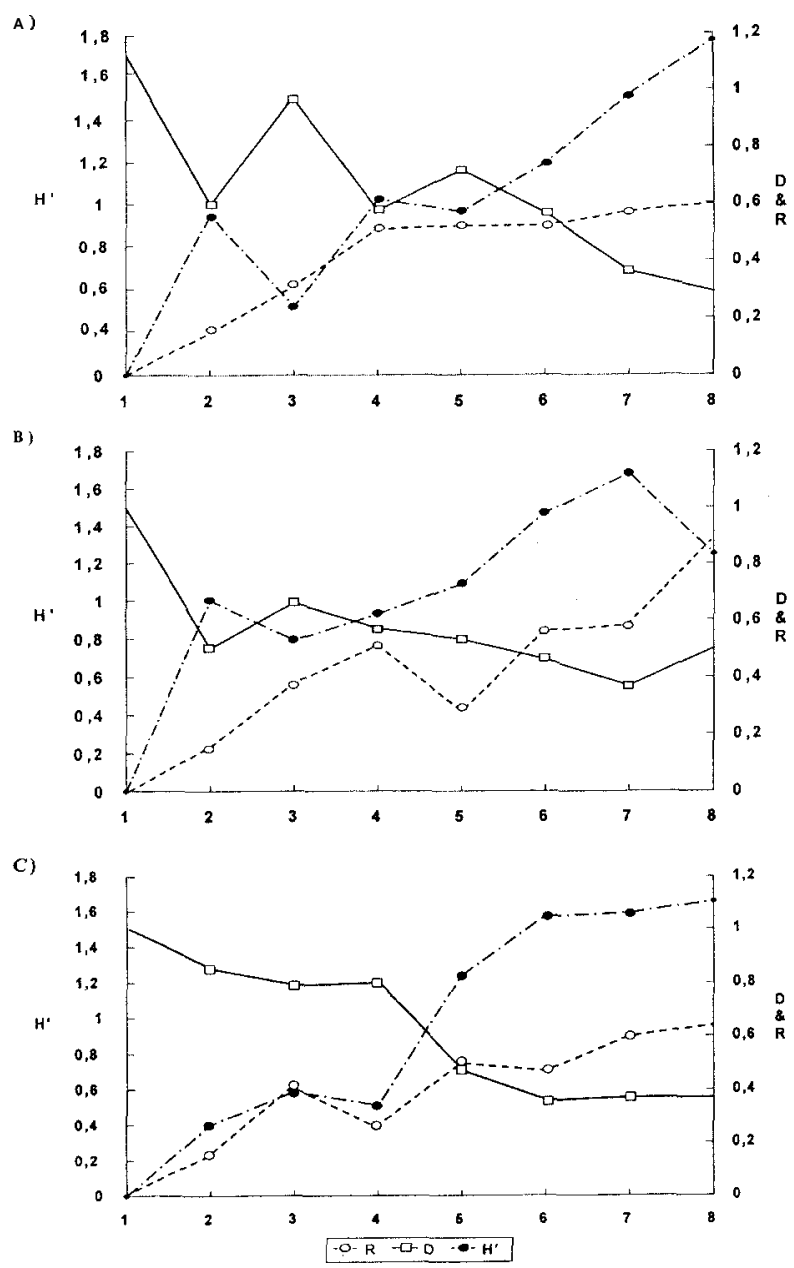

FIGURE 3. Dibersity (H'), dominance (D) and species richness (R) at the eight sampling stations in A) September 1994, B) May 1995 and C) September 1995.
In 1995 some man-madc alterations affected sampling stations $5, \mathrm{~h}$ and 7 (Table 2). At station 5 the total number of fish captures were significantly less than in $1994\left(\chi^{2}=2124\right.$, ldf, $\mathrm{p}<0.001)$, especially those of brown trout and minnow $\left(\chi^{2}=10.4\right.$, Idf, $p<0.001$ and $\chi^{2}=275.3$, Idf, $p<0.001$, respectively), although stone loach captures increased $\left(\chi^{2}=5.6\right.$, Idf, $p<0.05$ ). There were significant differences in the total number of fish captures between September 1994 and September 1995, probably as a consequence of the recolonization of the altered sampling point $\left(\chi^{2}=100.8\right.$, Idf, $\mathrm{p}<0.001)$. This was mainly due to stone loach $\left(\chi^{2}=402.1\right.$, ldf, $\mathrm{p}<0.001)$ and french nase $\left(\chi^{2}=43.8\right.$, Idf, $\left.\mathrm{p}<0.001\right)$. The brown trout population in this station decreased significantly between the two samplings undertaken in September 1994 and September $1995\left(\chi^{2}=22.0\right.$, Idf, $\left.p<0.001\right)$.

At station 6 the river bed was dredged before May 1995 . The total number of captures was less than in September 1994 $\left(\chi^{2}=247.8\right.$, Idf, $\left.\mathrm{p}<0.001\right)$, as well as the number of minnow captures $\left(\chi^{2}=193.9\right.$, Idf, $\left.p<0.001\right)$, however, there was an increase in stone loach numbers $\left(\chi^{2}=60.6\right.$, Idf, $\left.p<0.001\right)$. In September 1995, the total number of captures was higher than in May $1995\left(\chi^{2}=2350.1\right.$, Idf, $\left.p<0.001\right)$, and this was true for stone Ioach, minnow and french nase captures $\left(\chi^{2}=1450.6\right.$, Idf, $\mathrm{p}<0.001, \chi^{2}=569.6$, Idf, $\mathrm{p}<0.001$ and $\chi^{2}=518.7$, Idf, $\mathrm{p}<0.001$, respectively). These changes suggest a recolonization of the affected area by the stone loach.

At station 7 riparian and instream vegetation was removed before and after May 1995 sampling. The total number of captures of all species combined decreased significantly between September 1994 and September $1995\left(\chi^{2}=61.3\right.$, Idf, $\mathrm{p}<0.001)$, as well as of minnow and barbel $\left(\chi^{2}=38.9\right.$, ldf, $p<0.001$ and $\chi^{2}=56.9$, Idf, $p<0.001$, respectively).

\section{DISCUSSION}

Fluvial ecosystems follow longitudinal patterns of fish assemblages which are predictable to some extent according to the River Continuum Concept (VANNOTE et al., 1980). These patterns are related to increases in spatial heterogeneity and also affect the structure of the fish community increasing its diversity and richness (SCHLOSSER 1987; PRZYBYLSKI et al. 1991, PRZYBYLSKI 1993; STARMARCH et al., 1991; GARCÍA DE JALÓN, 1992). In the Urederra river this diversification of fish biocenosis could be clearly appreciated distinguishing two different sections: the upper course (dominated by brown trout) and the lower course, dominated by cyprinids (mainly minnow and french nase) and cobitids (stone loach). The diversity, dominance and species richness 
TABLE 2. Alterations observed in the Urederra River during the sampling period. Changes in fish populations arc also shown. S94: September 1994, M95: May 1995, S95: September 1995, n: number of fish.

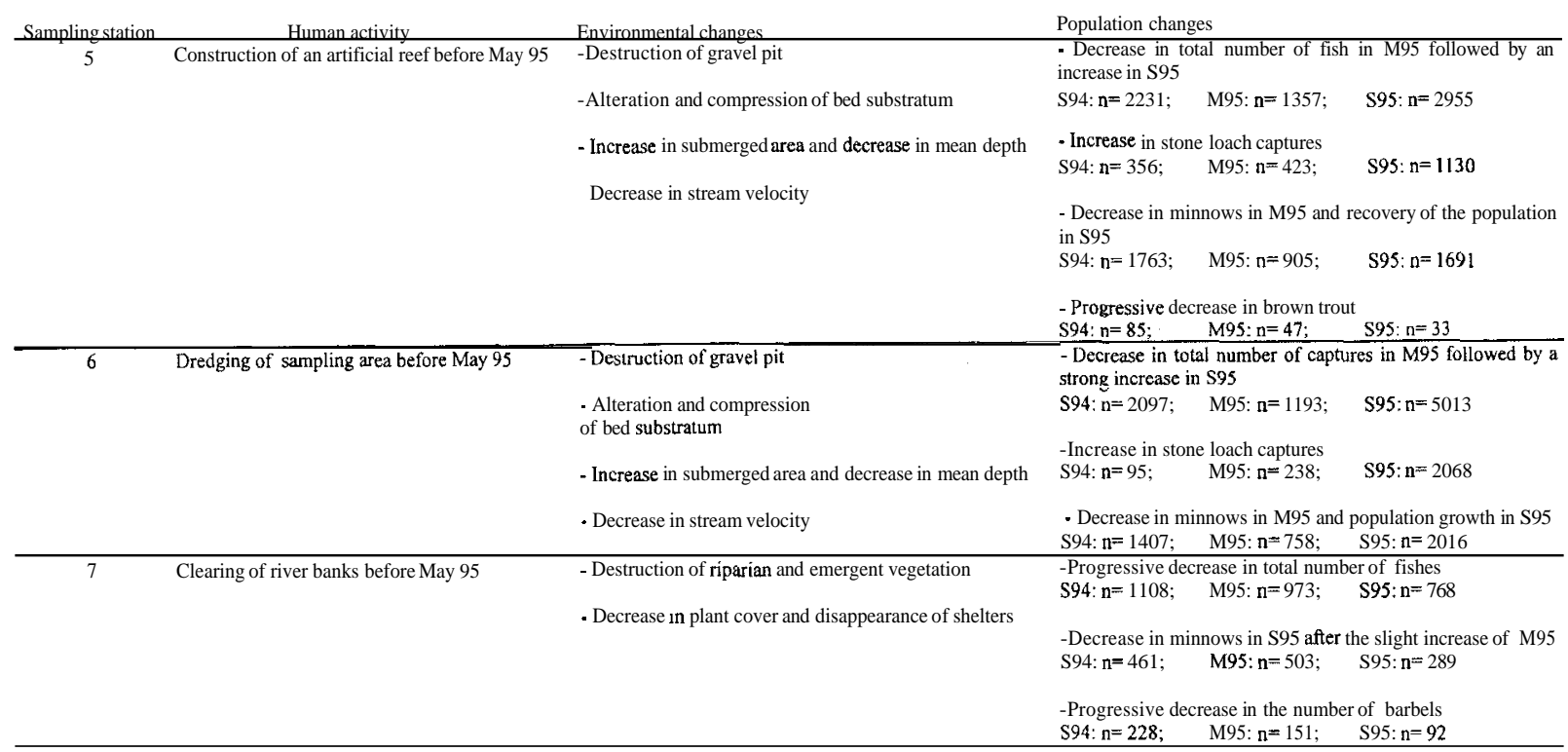

indices calculated at every sampling station followed patterns similar to other rivers in Europe (SCHLOSSER 1982, PRZYBYLSKI et al. 1991, STARMACH et al. 1991, PRZYBYLSKI 1993).

Alterations made to vegetation and bed structure in this river probably affected the total number of fish captures and the relative abundance of stone loach, minnow, barbel and brown trout. Something similar has been also reported by KENNEDY et al. (1983), COLLARES-PEREIRA et al. (1995) and COPP \& BENNETTS (1996) for other water courses in Europe.

Stone loach prefer clear, shallow, running waters being more abundant in stony and gravel areas (SAUVONSAARI 1971, MASTRORILLO et al. 1996). Bed modifications (compression and changes in substratum size) in stations 5 and 6 could favour recolonization by this species.

Diminution in barbel captures in station 7 were probably influenced by macrophyte cover elimination cover modifications which maybe originated the loss of shelters, as observed by COPP \& BENNETTS (1996) for Barbus barbus.

The changes in the numbers of minnow captures at stations 5,6 and 7 also seemed to be influenced by bank and bed alterations. This species recolonized stations 5 and 6 but not station 7. This suggests that aquatic vegetation could be especially important for this species.

\section{ACKNOWLEDGEMENTS}

This investigation has been partially supported by the Caja Rural de Navarra. We specially thank Luis Fernández-Acha (Sociedad de Pesca de Estella), landowners and all the people that collaborated in the field work. The Departamento de Agricultura, Ganaderia y Montes del Gobierno de Navarra supplied meteorological data from the station located at Amillano.

\section{REFERENCES}

COLlARES-PEREIRA, M.J., MAGALHAES, M.F., GERALDES, A. M., COELHO, M.M. 1995. Riparian ecotones and spatial variation of fish assemblages in Portuguese lowland streams. Hydrobiologia, 303: 93-101.

COPP, G.H., BENNETTS T.A. 1996. Short-term effects of removing riparian and instream cover on barbel (Barbus barbus) and other fish populations in a stretch of english chalk stream. Folia Zoológica, 45(3): 283-288.

GARCÍA DE JALON, D., LÓPEZ ALVAREZ, J.V. 1983. Distribución geográfica y mesológica de las espccies piscicolas de la cuenca del Duero en el verano de 1981. Actas del I Congreso Español de Limnología, Barcelonu: 277-235. 
GARCÍA DE JALON, D. 1992. Dinámica de las poblaciones piscicolas en los rios de montaiia ibéricos. Ecología, 6: 281296.

KENNEDY,G.J.A., CRAGG-HINE D., STRANGE C.D., STEWART D.A. 1983. The effects of a land drainage scheme on the salmonid populations of the River Camowen, Co. Tyrone. Fish Mgmt., 14: 1-16.

MARGALEF, R. 1989. Ecología. Editorial Omega, Barcelona. MASTRORILlo, S., DAUBA, F., BELAUD, A. 1996. Utilisation des microhabitats par le vairon, le gaujon et la loche Franche dans trois rivières du sud-ouest de la France. Annls. Litnnol., 32: 185-195.

PENCZAK, T., ZALEWSKI, M. 1981. Qualitative and tentative quantitative estimates of the fish stock based on three successive electrofishings in the medium-sized Pilica River. Pol. Arch. Hydrobio., 28: 55-68.

PENCZAK, T., ZALEWSKI, M., SUSZYCKA, E., MOLINSKI, M. 1981. Estimation of the density, biomass and growth of fish population in two small lowland rivers. Ekol. Pol., 29: 233-255.

PRZYBYLSKI, M. 1993. Longitudinal patterns in fish assemblages in the upper Warta River. Poland. Arch. Hydrobiol., 126: 499-5 12.

PRZYBYLSKI, M., BIRO, P., ZALEWSKI, M., TATRAI, Y., FRANKIEWICZ, P. 1991. The strutucture of fish communities in stream of the northern part of the catchment area of Lake Balaton (Hungary). Acta Hidrobiol., 33: 135148.

SAUVONSAARI, J. 1971. Biology of the stone loach (Ne- macheilus barbatulus L.) in the lakes Päijäne and Pälkänevesi, southern Finland. Ann. Zool. Fennici., 8: 187193.

SCHLOSSER, I.J. 1982. Fish communitye structure and function along two habitat gradients in a headwater stream. Ecological Monographs, 52: 395-414.

SCHLOSSER, I.J. 1987. A conceptual framework for fish communities in small warwater streams. In: W.J. Mathews \& D.C. Heins (Eds.).Community and evolutionary ecology of North American stream fishes. Oklahoma Univ. Press, Norman, Oklahoma.

SCHLOSSER, I.J. 1988. Predation risk and habitat selection by two size classes of a stream cyprinid: experimental test of a hypothesis. Oikos, 52: 36-40.

STARMACH, J., FLEITUCG, T., AMIROWICZ, A., MAZURKIEWICZ, G., JELONEK, M. 1991. Longitudinal patterns in fish communities in a Polish mountain river: their relation to abiotic and biotic factors. Actu Hidrobiol., 33: 353-366.

SOKAL, R.R., ROHLF, F.J. 1979. Biometría. Ediciones Blume. Barcelona.

VANNOTE, R.L., MINSHALL, G.W., CUMMINS, K.W., SEDELL, J.R., CUSHING, C.E. 1980. The River continuum concept. Can. J. Fish. Aquat. Sci., 37: 130-137.

ZALEWSKI, M., FRANKIEWICZ, P., PRZYBYLSKI, M., BANBURA, J., NOWAK, M. 1990. Structure and dynamics of fish communities in temperate rivers in relation to the abiotic-biotic regulatory continuum concept. Pol. Arch. Hydrobiol., 37: 151-176. 